\title{
The relationship between terpenes and flammability of leaf litter
}

\author{
Elena Ormeño ${ }^{\mathrm{a}, *}$, Blanca Céspedes ${ }^{\mathrm{b}}$, Iván A. Sánchez ${ }^{\mathrm{b}}$, Angel Velasco-García ${ }^{\mathrm{b}}$, José M. Moreno ${ }^{\mathrm{b}}$, \\ Catherine Fernandez ${ }^{c}$, Virginie Baldy ${ }^{\mathrm{c}}$ \\ ${ }^{a}$ Division of Ecosystem Sciences, Department of Environmental Science, Policy, and Management (ESPM), Berkeley University of California, 251A Mulford Hall, Berkeley, CA 94720, USA \\ ${ }^{\mathrm{b}}$ Departamento de Ciencias Ambientales/Department of Environmental Sciences, University of Castilla-La Mancha, Av. Carlos III s/n, Toledo, Spain \\ ${ }^{\mathrm{c}}$ Equipe Diversité Fonctionnelle des Communautés Végétales (DFCV), IMEP (UMR CNRS 6116), Aix-Marseille Université, Campus de St Jérôme, Case 421, Avenue Normandie, Niemen, \\ 13397 Marseille Cedex 20, France
}

\section{A R T I C L E I N F O}

\section{Article history:}

Received 29 June 2008

Received in revised form 8 September 2008

Accepted 9 September 2008

\section{Keywords:}

Fire risk

Leaf flammability

Ignitability

Litter fuel

Pinus sp.

Cistus sp

\begin{abstract}
A B S T R A C T
Many studies have assumed that plant terpenes favor fire due to their enormous flammability. However, only a few of them, all performed on green leaves, have demonstrated this. In the present work we investigated the question of whether litter terpene content can be used to estimate flammability and temperatures reached during fire. Epiradiator and burn table tests were used to compare flammability of leaf litter of $P$. pinaster, $P$. halepensis, $P$. pinea, $C$. albidus, $C$. ladanifer, $C$. laurifolius and the mixture of litter of P. pinaster with that of the other five species (e.g. P. pinaster + P. halepensis). Tests with burn table showed increasing spread rates and shorter combustion times under higher terpene contents. Flame height was triggered both with higher a terpene content and bed thickness, whereas the percentage of burned biomass was only significantly correlated to bed height. Epiradiator tests indicated that terpene concentration in leaf litter was positively correlated to flame height and negatively correlated to both flame residence time and ignition delay. Flammability was high for $P$. pinaster, $P$. halepensis, and hence for $P$. pinaster $+P$. halepensis, intermediate for $C$. albidus, $P$. pinea and $P$. pinaster combined with each of these species, and low for $C$. laurifolius, $C$. ladanifer and $P$. pinaster combined with them. Accordingly, their terpene content was high, intermediate and low. We concluded that plants might influence fire intensity, by having stored terpenes in their dead leaves, in addition to having developed traits to survive fire. Thus, a correct management of dead aboveground fuels rich in terpene concentrations, such as those of $P$. pinaster and $P$. halepensis, could prove helpful in reducing the hazard of fire.
\end{abstract}

(c) 2008 Elsevier B.V. All rights reserved.

\section{Introduction}

Fire is of great ecologic and economic import since it is the main factor responsible for the loss of forest covered surface in the Mediterranean area; since the late 1980s, Southern Europe (Portugal, Greece, Spain, France and Italy) has lost on average more than 500000 ha year $^{-1}$ of forest surface (European Commission, 2006). Although fires are mostly anthropogenic, knowledge of natural factors favoring fire could assist in forest management which might minimizes the consequences of fire.

Intrigued by the impact of these natural factors, researchers from several disciplines have focused on the variation of plant flammability and fire regimes in relation to: leaf morphology (Montgomery and Cheo, 1971), canopy architecture (Schwilk,

\footnotetext{
* Corresponding author. Tel.: +1 510642 9732; fax: +1 5106435098 .

E-mail address: elenaormeno@nature.berkeley.edu (E. Ormeño).
}

2003), floristic compositions (Brooks et al., 2004), germination strategies (e.g. seeders or resprouters, Scarff and Westoby, 2006) and plant chemical composition, such as water (Trabaud, 1976; Alessio et al., 2008a), lignin (Mackinnon, 1987), carbohydrates (Nimour Nour, 1997) and minerals (Mutch and Philpot, 1970) plant contents.

In contrast, flammability changes due to terpene content in plants have received little attention. Terpenes are unsaturated hydrocarbons that belong to a family of natural products issued from plant secondary metabolism and made up of isoprene units $\left(C_{5}\right)$. Some of these compounds, such as the volatile monoterpenes $\left(C_{10}\right)$ and the semi-volatile sesquiterpenes $\left(C_{15}\right)$ respectively, are stored in specialized structures such as lysigenous glands (e.g. in Gossypium hirsutum L.), trichomes (e.g. in Cistus sp.), cavities, ducts, canals, or resin ducts, in conifers (Walter et al., 1989). These compounds present an elevated flammability (Nuñez-Regueira et al., 2005), owing to their high heating value, relatively low flash point and Low Flammability Limit (LFL), as reported by numerous 
chemical manufacturers's Material Safety Data Sheets. For instance, limonene (99\% purity) shows a flash point of $43{ }^{\circ} \mathrm{C}$ and a LFL of $0.7 \%$ (Fluka Safety Data). Therefore, at relatively low temperatures and concentrations, liquid terpenes are capable of generating an ignitable mixture, leading to a flame in the presence of an ignition source, under specific test conditions (Affens and Carhart, 1966).

Numerous authors have hypothesized or even assumed that terpenes in plants have some responsibility in ecosystem functioning through their impact in flammability and hence fire (White, 1994; Llusià and Peñuelas, 2000; Nuñez-Regueira et al., 2005; Ormeño et al., 2007). White (1994) hypothesized that monoterpenes retained in litter enhance the frequency of fire. Nuñez-Regueira et al. (2005) assumed that the starting and spreading of forest fires is directly influenced by the essential oils/ resins contained in the woody species, due to the terpenes therein accumulated.

Nevertheless, in recent studies (Alessio et al., 2008a,b), the effect of terpene content on leaf flammability was inexistent or inconclusive. Only the study of Owens et al. (1998) has provided clear evidence on the relationship between leaf flammability (consumability) and terpene concentration. These authors reported a higher flammability for green leaves of Juniperus ashei with higher D-limonene concentrations, and the opposite behavior for bornyl acetate. They concluded that terpenes favored green leaf flammability when they were at a liquid state under ambient temperatures.

Surface fuels, such as leaf litter, may also contain important terpene concentrations, as shown by Isidorov et al. (2003) for conifer species. In addition, in semi-arid climates, where above-ground litter accumulation is favored due to low decomposition rates (Mitchell et al., 1986), surface fuels such as litter seem to be crucial for fire risk since they influence its transmission (Bradstock and Cohn, 2002; Hogkinson, 2002). In southern Europe, litter of Pinus pinaster Aiton. is of major importance since afforestation of communal lands with dense stands of $P$. pinaster, rather than Pinus halepensis Mill. and Pinus pinea $\mathrm{L}$., has replaced the traditional matrix of grazed shrublands and pastures in Spain in the 20th century. $P$. pinaster is also the main conifer used in afforestation in France (Derory et al., 2002). This species exceeds 4 million ha in the Mediterranean Basin (Alía et al., 1996) and it accounted for 35\% of the burned forest area between 1974 and 1994 in Spain (Pausas and Vallejo, 1999). Besides, 48\% of the forested area that burned in the 1990s consisted of pure $P$. pinaster stands in Portugal (Pereira and Santos, 2003). Despite the importance of dead matter fuels in wildfire and the accumulation of terpenes within them, the question of whether terpene content increases flammability of this fuel remains unexplored.

The objectives of the present investigation were to evaluate the possibility of using terpene content of leaf litter to estimate flammability changes and temperatures reached during fire, and to establish a flammability ranking for the leaf litter fuels studied. According to Behm et al. (2004), flammability components analyzed were: (1) ignitability, the time until ignition occurs, when fuel is exposed to a flame or other heat source; (2) combustibility, a reflection of how rapidly or intensely a fuel is consumed by fire; (3) sustainability, a measure of how well a fire burns with or without a heat source; (4) consumability, the quantity of the fuel that is consumed during a fire.

\section{Materials and methods}

\subsection{Sampling and studied species}

Flammability tests were performed under controlled conditions on leaf litter of six species: P. pinaster, $P$. halepensis, $P$. pinea, Cistus albidus L., Cistus ladanifer L., and Cistus laurifolius L. Mixed leaf litters, formed by the combination of leaf litter of $P$. pinaster together with that of the other five species (i.e. $P$. pinaster $+P$. halepensis, $P$. pinaster $+P$. pinea, $P$. pinaster $+C$. albidus, $P$. pinaster $+C$. ladanifer, $P$. pinaster $+C$. laurifolius), were also studied. Hence, a total of eleven leaf litter combinations were analyzed.

Litter collection took place from May through June 2007. Leaf litter of $P$. halepensis and C. albidus was collected in Le Petit Arbois $\left(46^{\circ} 56^{\prime} \mathrm{N}-5^{\circ} 40^{\prime} \mathrm{E}\right.$, Southern France) and Luminy $\left(43^{\circ} 13^{\prime} \mathrm{N}-5^{\circ} 25^{\prime} \mathrm{E}\right.$, Marseille, Southern France). Litter of $C$. ladanifer came from Cerro Jaralón $\left(40^{\circ} 26^{\prime} \mathrm{N}-4^{\circ} 17^{\prime} \mathrm{W}\right.$, next to Collado Mediano, Madrid, Central Spain). In case of $C$. laurifolius, litter was sampled next to Cerro Golondrina $\left(40^{\circ} 25^{\prime} \mathrm{N}-4^{\circ} 18^{\prime} \mathrm{W}\right.$, Navacerrada, Madrid, Central Spain). Leaf litter of $P$. pinaster and $P$. pinea was collected in Quintos del Pinar $\left(39^{\circ} 23^{\prime} \mathrm{N}, 4^{\circ} 03^{\prime} \mathrm{W}\right.$, Toledo, central Spain). In all cases current leaf litter from the superficial soil layer was collected. To facilitate leaf litter separation and ensure litter purity, collection of fallen leaves took place from litter islands beneath monotypic and dense stands, where plants were well separated from other plants with leaves of similar appearance. Leaf litter from 20 to 30 mature individuals per species was collected.

After collection, litter of all species was sorted one leaf at a time. Litter from animal origin, stems, cones, branches and leaf litter of other species were removed. As water is recognized as one of the most important factors that influence fire behavior, leaf litter of all species was oven-dried at $40{ }^{\circ} \mathrm{C}$ until achieving a constant weight, to avoid the possibility that water mitigates terpene content effect. Drying temperature was close to average maximum summer temperatures often occurring in selected sites. The slight humidity remaining in leaf litter samples was calculated with a moisture analyzer ("Mettler Toledo HB43 halogen"). Remaining humidity accounted for $2-3 \%$ of total litter mass and was similar for all types of leaf litter. Flammability measurements took place through June and July 2007.

\subsection{Flammability and temperature measurements accomplished via a burn table}

Fuel burns were performed on a horizontal and fire-resistant table of $2 \mathrm{~m}$ long and $1.5 \mathrm{~m}$ width, constructed of Barlán ${ }^{\odot}$ material. In one of the lateral sides of the table, a set of previously calibrated k-type thermocouples of $1 \mathrm{~mm}$ diameter was used to register temperature data reached during experimental burns. Three thermocouples were positioned at the litter surface and spaced along the surface of the table (position 1: $20 \mathrm{~cm}$, position 2: $60 \mathrm{~cm}$ and position 3: $100 \mathrm{~cm}$ ). They were connected to a computer through e-console version 3.1 software, showing registered temperatures in real time. This information was then exported for subsequent data treatment. On the other lateral side of the table a warm glass insulated the environment where each fuel bed was burnt to isolate the area from the environmental laboratory.

Fuel beds consisted of $1 \mathrm{~kg}$ of dry leaf litter extended in $1 \mathrm{~m}^{2}$ (i.e. fuel load $=1 \mathrm{~kg} / \mathrm{m}^{2}$ ). When leaf litter bed was composed of two species, that is, when litter of $P$. pinaster was mixed with litter of any of the 5 other species, $500 \mathrm{~g}$ of leaf litter of each species were used. Thus, leaf litter dry mass used was $10.5 \mathrm{~kg}$ for $P$. pinaster, and $4.5 \mathrm{~kg}$ for each of the other species. To ensure that leaf litter was uniformly placed on the table where the experimental burns took place, fuel bed thickness was measured at 5 points per sample, before fire was set. After leaf litter was positioned on the burn table, ignition occurred via a short pilot flame placed at the beginning of one edge of the combustion table for a few seconds to initiate ignition (Morandini et al., 2001).

Leaf flammability parameters considered during burn tables were (1) combustion time (sustainability measure), measured as 
the time flame was visible from ignition until fire extinction, (2) spread rate, calculated as the ratio between the length of the burned surface and the residence time, (3) maximal flame height (combustibility measure), calculated by means of marks (labeled posts), taken as reference (4) percentage of burned mass (consumability measure), calculated as the difference between fuel mass before and after flame extinction. In addition to leaf flammability, maximum, minimum and mean temperatures, calculated by considering temperatures recorded in thermocouples, were also measured. Flammability and temperatures were measured on 3 fuel beds for each leaf litter combination. During burns, mean relative humidity and temperature were $51 \%$ and $23^{\circ} \mathrm{C}$.

\subsection{Flammability measurements through epiradiator tests}

Leaf litter flammability was determined using a standard epiradiator delivering a $500 \mathrm{~W}$ constant nominal power rating (Hernando-Lara, 2000). The epiradiator showed a surface made of a vitreous fused silica disk of $100 \mathrm{~mm}$ diameter generating an infrared wavelength of $300 \mathrm{~nm}$ and a surface standard temperature of $420^{\circ} \mathrm{C}$. The produced radiation ranged between 3.0 and $7.5 \mathrm{~W} /$ $\mathrm{cm}^{2}$ at $30 \mathrm{~mm}$ over the silica disk.

For each leaf litter type, flammability was measured on 30 samples of $1.0 \pm 0.1 \mathrm{~g}$ (Hernando-Lara, 2000; Petriccione et al., 2006; Pellizzaro et al., 2007), as larger fuel masses increases the possibility that other fuel properties, such as fuel height, are involved in flammability changes. The mass used also appeared to be the most appropriate in the light of the range of flammability observed. Leaf litter was always set in the center of the silica disk. When leaf litter of $P$. pinaster was burned together with any of the other species, $0.5 \mathrm{~g}$ of each leaf litter were used to perform flammability tests.

Flammability parameters measured through this protocol were (1) ignition delay (ignitability measure), considered as the time flame took to appear since fuel was set in the epiradiator, (2) flame residence time (sustainability measure), measured as the time flame was visible, (3) flame intensity (combustibility measure), estimated as a qualitative score assigned according to the maximum flame height. Flame intensity was comprised between 1 and 5 when flame height generated during combustion was $<1 \mathrm{~cm}$, between 1 and $3 \mathrm{~cm}, 4$ and $7 \mathrm{~cm}, 8$ and $12 \mathrm{~cm}$ or $>12 \mathrm{~cm}$, respectively (CEREN, 2006). All tests were conducted in a closed environment, avoiding any effect associate with the movement of air. During tests, relative mean humidity was $56 \%$ and mean temperature $20^{\circ} \mathrm{C}$.

\subsection{Terpene extraction and analysis}

Previous to terpene extraction, leaf litter was mechanically ground with a grinder. Before analysis, ground litter was 12-mesh $(1.68 \mathrm{~mm})$ sieved. The extraction method used was that applied in Ormeño et al. (2007) for green leaves, but slightly modified. It consisted in dissolving $1 \mathrm{~g}$ of leaf DM in $5 \mathrm{ml}$ of organic solvent, for $1 \mathrm{~h}$, under constant shaking at room temperature (Ormeño et al., 2007). For mixed litters (those formed by $P$. pinaster and any of the other leaf litters) $0.5 \mathrm{~g}$ of each species was used for terpene extraction. Cyclohexane was used as organic solvent instead of hexane, as terpene concentration obtained with cyclohexane was $20 \%$ higher than that obtained with hexane. Well-filled, tightly closed glass vials wrapped in aluminum foil were used to avoid exposure to light and oxygen (Guenther, 1949, in Farhat et al., 2001). For terpene quantification, a non-isoprenoid volatile internal standard (Dodecane) was added at concentrations close to those found in the litter. The extract was stored at $-20{ }^{\circ} \mathrm{C}$ and then analyzed within the $72 \mathrm{~h}$. Recovery was $92 \%$ and mean variation coefficient was 5\%. Three terpene extractions (each sample containing $1 \mathrm{~g}$ dry litter) were performed for each fuel bed, making a total of 9 extractions per fuel burned on the burn table. Terpene content of litter burned in the epiradiator was calculated as the average of these 9 samples.

Terpene analyses were performed using GC (Gas Chromatography, Hewlett Packard GC6890 ${ }^{\mathbb{R}}$ ) coupled to a Mass Selective Detector (MSD, HP 5973N). Terpene separation was achieved in a HP-5MS capillary column, in constant flow mode. Injection of sampled volumes occurred through an automatic injector (ALS 7683). Helium (99.995\%) was used as carrier gas. The oven temperature was initially set at $50{ }^{\circ} \mathrm{C}$ and then increased to $160{ }^{\circ} \mathrm{C}$ at a rate of $2{ }^{\circ} \mathrm{C} / \mathrm{min}$. It then remained constant for $5 \mathrm{~min}$. The parameters of the MSD for electron impact (EI) mode were: ion source: $230{ }^{\circ} \mathrm{C}$; MS quadrupole: $150{ }^{\circ} \mathrm{C}$; electron energy: 70 eve; electron multiplayer energy: $1200 \mathrm{~V}$. Data were acquired in scan mode from 40 to $500 \mathrm{amu}$.

Identity of leaf-stored terpenes was established by comparison of the retention time and the mass spectrum of detected compounds with those of the authentic reference samples (Aldrich-Firmenich). Terpene identity was then confirmed with generated libraries of retention indexes (Adams, 2007). To calculate terpene concentrations, the integrated area of each peak was multiplied by the appropriate response factor, and divided by the sample volume.

\subsection{Statistical analyses}

Differences in terpene content between the eleven leaf litter fuels were tested using one-way ANOVA followed by a post-hoc Duncan test. Terpene content was previously log-transformed to meet oneway ANOVA assumptions of normality and homoscedasticity. With the epiradiator technique, flammability differences among leaf litter combinations were also tested with a one-way ANOVA. Then, linear simple regression analyses (RA) were used to examine whether fuel flammability was correlated to fuel terpene content. With burn tables, differences in fire behavior (flammability and fire temperatures) among fuel types were assessed with Kruskal-Wallis, followed by the non-parametric post-hoc Newman Student Keuls (NSK) test. Multiple regression analysis (MRA) and RA were used to examine the relative importance of terpene content and bed height as predictor variables of fire behavior (flammability and fire temperatures). The independence of terpene content and bed height was previously tested. The significance level for including predictor variables in the MRA and for accepting the RA was 0.05. When terpene content was significantly correlated to variables describing fire behavior, RA was also performed using concentration of single terpenes. Single terpenes were selected for RA when they were at least present in 9 leaf litter fuels. To test which compounds lead to the most important changes in flammability, differences in slopes for different terpenes were assessed through Covariance analyses (ANCOVA) followed by Duncan multiple range test. Statistical analyses were carried out with Statistical Graphics Plus ${ }^{\circledR}$, version 4.1., R, and Statbas (DOS personal program Pr. P. Francour, University of Nice, France).

\section{Results}

\subsection{Fuel characteristics: leaf litter terpene concentration and bed height}

Terpene concentration was significantly different among leaf litter fuels (one-way ANOVA, $P<0.05$, Fig. 1). $P$. halepensis presented the highest terpene content $\left(5135.4 \pm 1590.6 \mu \mathrm{g} \mathrm{g}_{\mathrm{DM}}{ }^{-1}\right)$, 1), followed by $P$. pinaster $\left(706.2 \pm 107.9 \mu \mathrm{g} \mathrm{g}_{\mathrm{DM}}{ }^{-1}\right), \quad$. pinea 


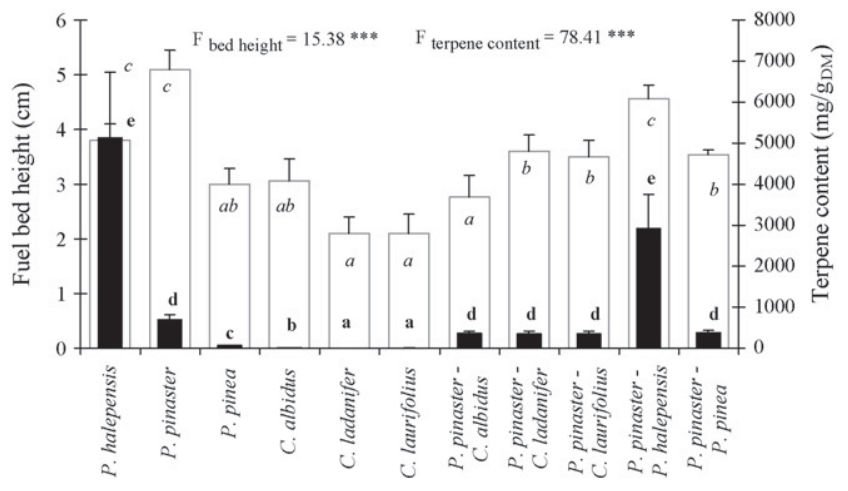

Fig. 1. Terpene concentration after log transformation (black bars) and bed height (white bars) of eleven leaf litter fuels. Differences between fuels are tested through one-way ANOVA, followed by Duncan test post-hoc. Differences are denoted by different bold letters for terpene content and italic letters for bed height. $\mathrm{a}<\mathrm{b}<\mathrm{c}<\mathrm{d}$. F: ANOVA value. Bars represent mean \pm S.E. $(n=9)$. $\left(64.5 \pm 4.0 \mu \mathrm{g} \mathrm{g}_{\mathrm{DM}}{ }^{-1}\right)$ and $C$. albidus $\left(18.4 \pm 2.1 \mu \mathrm{g} \mathrm{g}_{\mathrm{DM}}{ }^{-1}\right)$ (Duncan test, Fig. 1). On the contrary, leaf litter of $C$. ladanifer $\left(5.3 \pm 1.5 \mu \mathrm{g} \mathrm{g}_{\mathrm{DM}}{ }^{-1}\right)$ and $C$. laurifolius $\left(6.4 \pm 2.4 \mu \mathrm{g} \mathrm{\textrm {g } _ { \mathrm { DM } }}{ }^{-1}\right)$ showed the lowest leaf litter terpene concentrations. Hence, leaf litter formed by $P$. pinaster $+P$. halepensis presented higher terpene concentrations than $P$. pinaster combined with either $P$. pinea or Cistus sp.

Numerous terpenes were stored in leaf litter of the different species (Table 1). Except for $C$. ladanifer, sesquiterpenes were the most representative compounds in leaf litter. C. ladanifer essentially contained sabinene (16.2\%), $\beta$-pinene (13.9\%), $p$-cymene (12.1\%), all of them monoterpenes, and $\gamma$-cadinene (17\%) (sesquiterpene). Needle litter of $P$. halepensis showed the highest terpene diversity (thirty four terpenes). $\beta$-Caryophyllene $(62.0 \%)$ and $\alpha$-humulene (11.3\%) showed the highest percentages in respect of total content. $P$. pinaster and $P$. pinea contained similar terpene diversities, since nineteen terpenes were detected and quantified in their leaf litter. $P$. pinaster mainly contained $\beta$-caryophyllene $(32.4 \%)$ and $\gamma$-muurolene $(17.1 \%)$. P. pinea also showed $\beta$-caryophyllene as a major component of total terpene content (31.2\%), followed by caryophyllene oxide (13.8\%). Major compounds in C. albidus were:

Table 1

Terpene composition of leaf litter of three Pinus and Cistus species. Terpene content is expressed in \% of the total terpene content.

\begin{tabular}{|c|c|c|c|c|c|c|c|}
\hline RI & & P. halepensis & P. pinaster & P. pinea & C. albidus & C. ladanifer & C. laurifolius \\
\hline & & \multicolumn{6}{|c|}{ Monoterpenoid content (\%) } \\
\hline 933 & $\alpha$-Thujene & $1.1(0.3)$ & - & - & - & $5.2(1.6)$ & - \\
\hline 943 & $\alpha$-Pinene & $7.8(1.8)$ & $1.4(0.5)$ & $2.5(0.4)$ & - & $4.3(1.6)$ & $3.1(1.6)$ \\
\hline 976 & Sabinene & $1.8(0.5)$ & - & - & - & $16.2(9.8)$ & - \\
\hline 981 & $\beta$-Pinene & $1.5(0.4)$ & $0.2(0.1)$ & $1.5(0.7)$ & - & $13.9(5.9)$ & - \\
\hline 991 & $\beta$-Myrcene & $2.2(1.0)$ & - & - & - & - & - \\
\hline 996 & 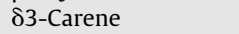 & $0.6(0.1)$ & - & - & - & - & - \\
\hline 999 & $\alpha$-Phellandrene & $0.1(0.0)$ & - & $0.1(0.0)$ & - & - & - \\
\hline 1002 & 4-Carene & $0.2(0.0)$ & - & - & - & - & - \\
\hline 1015 & $\alpha$-Terpinene & $0.1(0.0)$ & - & - & - & $3.4(0.3)$ & - \\
\hline 1021 & p-Cymene & $0.1(0.0)$ & - & $2.3(2,3)$ & - & $12.1(2.0)$ & $9.2(4.7)$ \\
\hline 1026 & Limonene & $0.6(0.2)$ & - & $6.7(3.4)$ & - & - & - \\
\hline 1045 & Trans- $\beta$-ocimene & $0.3(0.0)$ & - & - & - & - & - \\
\hline 1058 & $\gamma$-Terpinene & $0.5(0.2)$ & - & - & - & - & - \\
\hline 1082 & $\dot{\Delta}$-Terpinene & $2.1(1.0)$ & - & - & - & - & - \\
\hline 1101 & Linaool & $0.1(0.0)$ & - & - & - & - & - \\
\hline 1163 & Borneol & - & - & - & - & $3.3(1.1)$ & $3.9(2.0)$ \\
\hline 1171 & Terpinen-4-ol & $0.4(0.0)$ & - & - & - & - & - \\
\hline 1198 & Verbenone & $0.1(0.0)$ & - & - & - & - & - \\
\hline \multirow[t]{2}{*}{1280} & Bornyl acetate & $0.1(0.0)$ & - & - & - & $2.7(0.6)$ & - \\
\hline & & \multicolumn{6}{|c|}{ Sesquiterpenoid content (\%) } \\
\hline 1348 & $\alpha$-Cubebene & $0.3(0.0)$ & $3.4(0.6)$ & $1.2(0.1)$ & $4.3(0.5)$ & - & $3.5(1.9)$ \\
\hline 1368 & Ylangene & $0.1(0.0)$ & $1.1(0.3)$ & - & - & - & $1.4(0.1)$ \\
\hline 1371 & $\alpha$-Copaene & $1.0(0.0)$ & $3.3(0.8)$ & $1.7(0.1)$ & - & - & $4.3(1.8)$ \\
\hline 1380 & $\beta$-Bourbonene & - & $0.4(0.1)$ & - & $13.7(2.3)$ & - & - \\
\hline 1382 & $\beta$-Cubebene & $0.3(0,0)$ & $2.9(0.5)$ & $0.8(0.1)$ & $1.8(0.2)$ & - & $2.5(1.2)$ \\
\hline 1400 & $\beta$-Elemene & $0.2(0.0)$ & - & - & - & - & - \\
\hline 1405 & Longifolene & - & $1.4(0.1)$ & $9.2(0.6)$ & - & - & $6.0(2.9)$ \\
\hline 1417 & $\beta$-Cedrene & - & - & - & - & - & $2.7(0.6)$ \\
\hline 1415 & $\beta$-Caryophyllene & $62.0(18.2)$ & $32.4(2.8)$ & $31.2(1.8)$ & $5.2(1.3)$ & $8.4(2.8)$ & $13.6(5.4)$ \\
\hline 1435 & Aromadendrene & $0.1(0.0)$ & $0.3(0.0)$ & $1.8(0.3)$ & - & - & - \\
\hline 1450 & a-Humulene & $11.3(3.8)$ & $6.1(0.6)$ & $7.1(0.3)$ & - & - & $6.7(1.9)$ \\
\hline 1459 & Allo-aromadendrene & - & - & - & $7.1(3.8)$ & - & - \\
\hline 1469 & $\gamma$-Muurolene & $0.2(0.0)$ & $17.1(4.9)$ & $6.6(0.6)$ & $1.3(0.5)$ & $7.6(3.6)$ & $11.5(4.6)$ \\
\hline 1471 & D-germacrene & $0.6(0.2)$ & $8.7(2.0)$ & $4.0(0.1)$ & - & - & - \\
\hline 1480 & AR-Curcumene & - & - & - & $16.9(7.2)$ & - & - \\
\hline 1487 & Valencene & - & $1.5(0.3)$ & $0.7(0.2)$ & $1.3(0.2)$ & - & - \\
\hline 1490 & $\alpha$-Zingiberene & - & - & - & $2.3(0.3)$ & - & - \\
\hline 1492 & $\alpha$-Muurolene & $0.2(0.0)$ & $0.6(0.3)$ & $0.2(0.1)$ & - & - & $2.4(0.6)$ \\
\hline 1497 & $\beta$-Bisabolène & $0.1(0.1)$ & $3.9(1.9)$ & - & - & - & - \\
\hline 1508 & $\gamma$-Cadinene & $1.3(0.1)$ & $3.8(1.8)$ & $1.4(0.5)$ & $6.7(3.3)$ & $17.0(5.3)$ & $10.9(4.0)$ \\
\hline 1510 & $\delta$-Cadinene & $0.8(0.1)$ & $6.1(2.6)$ & $2.9(1.1)$ & $5.0(1.2)$ & $5.9(2.9)$ & $9.5(3.3)$ \\
\hline 1520 & Elemol & $0.6(0.1)$ & - & - & - & - & - \\
\hline 1562 & Caryophyllene oxide & $1.2(0.1)$ & $5.4(1.9)$ & $13.8(5.4)$ & $34.3(4.8)$ & - & $11.3(5.4)$ \\
\hline 1581 & Guaiol & - & - & - & $4.0(1.9)$ & - & - \\
\hline
\end{tabular}

RI: Retention index; (-): non-detected compound; values shown are mean \pm standard error in parenthesis for $n=10$; values in bold denote major compounds (at least $10 \%$ of total content); percentages are calculated in respect of total content. 

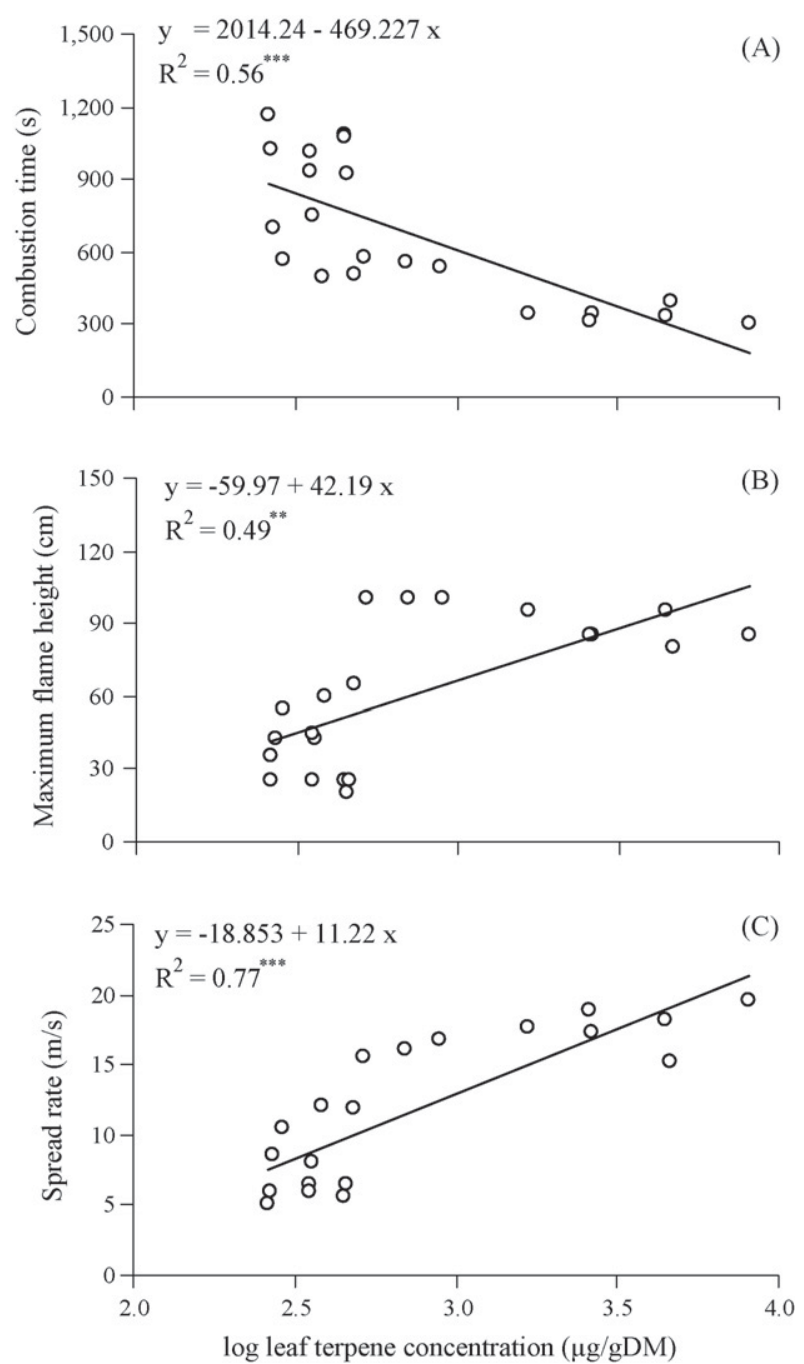

Fig. 2. Correlation between total terpene concentration (after log transformation) in leaf litter and combustion time (A), flame height (B), and spread rate (C) obtained with burn table. Correlations with the rest of fire properties (percentage of burned biomass and fire temperatures) were not significant in MRA and are not shown. Only data of fuels where fire was propagated are shown (P. pinaster, $P$. halepensis, $P$. pinaster $+P$. halepensis, $P$. pinaster $+P$. pinea, $P$. pinaster $+C$. albidus, $P$. pinaster $+C$. ladanifer, $P$. pinaster $+C$. laurifolius). $n=21$, since 3 fuel beds were studied for each fuel type.

caryophyllene oxide (34.3\%), followed by ar-curcumene (17.0\%). For C. laurifolius, main compounds stored in leaf litter were $\beta$ caryophyllene (13.6\%), $\gamma$-muurolene (11.3\%), caryophyllene oxide (11.3\%), and $\gamma$-cadinene (10.9\%).

Special attention was further paid to $\beta$-pinene, $\alpha$-humulene $\beta$ caryophyllene, $\gamma$-cadinene, $\delta$-cadinene, $\gamma$-muurolene, caryophyllene oxide since they appeared as major compounds in some species and were present in most litter types (at least 9 litter types among the 11 studied). Since ar-curcumene and sabinene were absent in most of the fuels (e.g. the former was only detected in $C$. albidus, Table 1) they were not selected to study in detail their effects on flammability despite being major compounds in some fuels. In contrast, $\alpha$-pinene was selected, even if this compound was not present as a major compound in any litter, with the exception of $C$. albidus.

Fuel beds also differed in their height. The highest bed heights appeared for leaf litter of $P$. pinaster and $P$. pinaster $+P$. halepensis (bed height ranged between 4 and $5 \mathrm{~cm}$ ). The lowest bed thicknesses $(2 \mathrm{~cm})$ were those of leaf litter $C$. ladanifer and $C$.

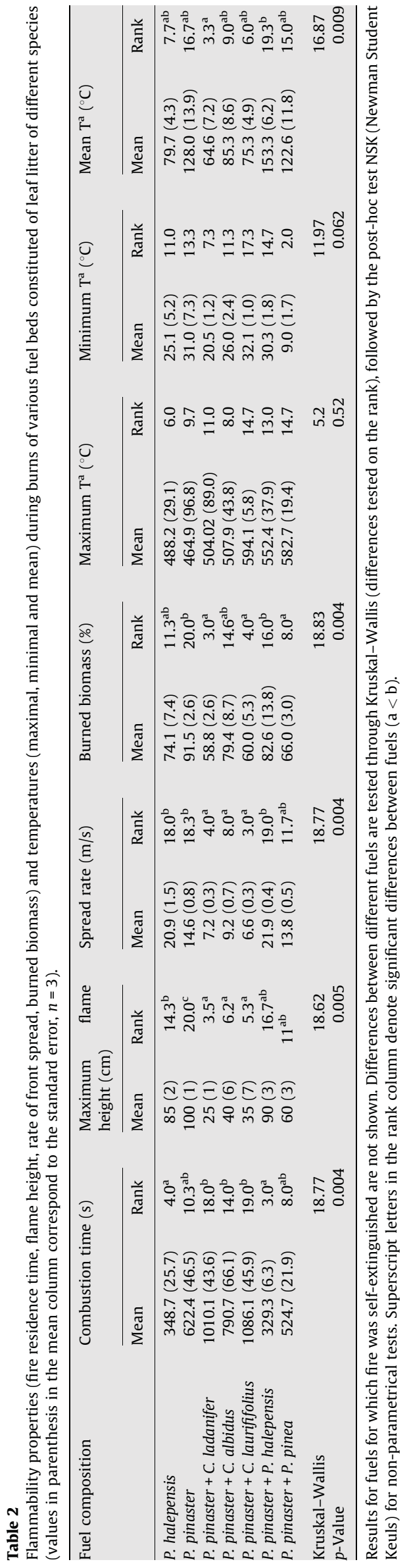


laurifolius (Fig. 1). The rest of leaf litter beds showed intermediate thicknesses ranging from 2.8 to $3.8 \mathrm{~cm}$.

\subsection{Leaf litter flammability and flame temperatures obtained through burn table and relationship with terpene content}

Only leaf litter of $P$. pinaster and $P$. halepensis (species with the highest terpene concentrations) sustained fire propagation until complete combustion occurred through the entire fuel bed surface. In other words, fire through leaf litter of $P$. pinea, and Cistus sp. was always self-extinguished after several $\mathrm{cm}$ (less than $10 \mathrm{~cm}$ ), and subsequent attempts to establish a self-sustaining fire failed. Hence, fire behavior (flammability and temperatures) were computed and monitored for fuel beds formed by leaf litter of $P$. pinaster, $P$. halepensis and $P$. pinaster together with the other five species, as can be checked in Fig. 2 and Table 2 .

Combustion time varied significantly among fuels (KruskalWallis, $P<0.05$, Table 2). The lowest combustion times (NSK, Table 2) occurred for litter beds of $P$. halepensis and $P$. pinaster $+P$. halepensis, whose terpene concentrations were the highest (Duncan test, Fig. 1). In comparison, when litter of $P$. pinaster was burned simultaneously with that of any Cistus species, time during which fire remained active was longer, indicating a longer combustion time and hence a lower sustainability for these fuel beds. Only terpene content explained variations in combustion time (MRA, bed height: $P>0.05$ terpene content, $P<0.01$, Table 3 ). Combustion time and terpene content exhibited a very strong negative relationship (RA, $P<0.001$, Fig. 2 A). Likewise, significant negative linear correlations appeared between combustion time and concentration of $\alpha$-pinene, $\alpha$-humulene, $\beta$-caryophyllene, $\gamma$ cadinene and caryophyllene oxide (RA, $0.0001<P<0.001$, Fig. 4A), with the highest $R^{2}$ for caryophyllene oxide $\left(R^{2}=0.61\right)$ and the lowest for $\alpha$-pinene $\left(R^{2}=0.50\right)$.

Flame height also varied significantly between fuel beds (Kruskal-Wallis, $P<0.05$, Table 2). P. pinaster showed the longest flames $(100 \mathrm{~cm})$, followed by $P$. pinaster $+P$. halepensis and $P$. halepensis (90 and $85 \mathrm{~cm}$, respectively), while P. pinaster + Cistus sp. showed the lowest flames (between 25.5 and $40.3 \mathrm{~cm}$ ). Flame height was positively correlated to both bed height and terpene concentration (MRA, bed height: $P<0.001$, terpene content: $P<0.01$, Table 3). A strong linear relationship appeared between flame height and either total terpene content (RA, $P<0.01$, Fig. 2B) or bed height (RA, $P<0.0001$, Fig. 3A). Concentrations of $\alpha$-pinene, $\alpha$-humulene, $\beta$-caryophyllene, $\gamma$-cadinene and caryophyllene oxide were also significantly correlated to flame height $(0.002<P<0.007$, Fig. 4B). The linear relationship was especially strong for caryophyllene oxide $\left(R^{2}=0.69\right)$ and weaker for $\alpha$-pinene $\left(R^{2}=0.57\right)$. Slopes of the linear relationships were significantly different (ANCOVA, $P<0.05$, Fig. 4B). $\alpha$-Pinene showed a smaller slope than sesquiterpenes (Duncan test), indicating that flammability is more sensitive to increased sesquiterpene than monoterpene concentration.

\section{Table 3}

Multiple regression analyses to examine whether variation in fire residence time, flame height, spread rate, burned biomass and mean temperature (dependent variables: $y$ ) obtained via a burn table can be estimated by terpene content and/or bed height (independent variables: $x$ ).

\begin{tabular}{llll}
\hline & $R^{2}$ & $\begin{array}{l}p \text {-Value terpene } \\
\text { content }\end{array}$ & $\begin{array}{l}p \text {-Value bed } \\
\text { height }\end{array}$ \\
\hline Combustion time (s) & 0.54 & $* * *$ & $\mathrm{~ns}$ \\
Maximum flame height $(\mathrm{cm})$ & 0.76 & $* *$ & $* * *$ \\
Spread rate (m/s) & 0.59 & $* * *$ & $\mathrm{~ns}$ \\
Burned biomass $(\%)$ & 0.34 & $\mathrm{~ns}$ & $*$ \\
Mean T $^{\mathrm{a}\left({ }^{\circ} \mathrm{C}\right)}$ & 0.41 & $\mathrm{~ns}$ & $* *$ \\
\hline
\end{tabular}
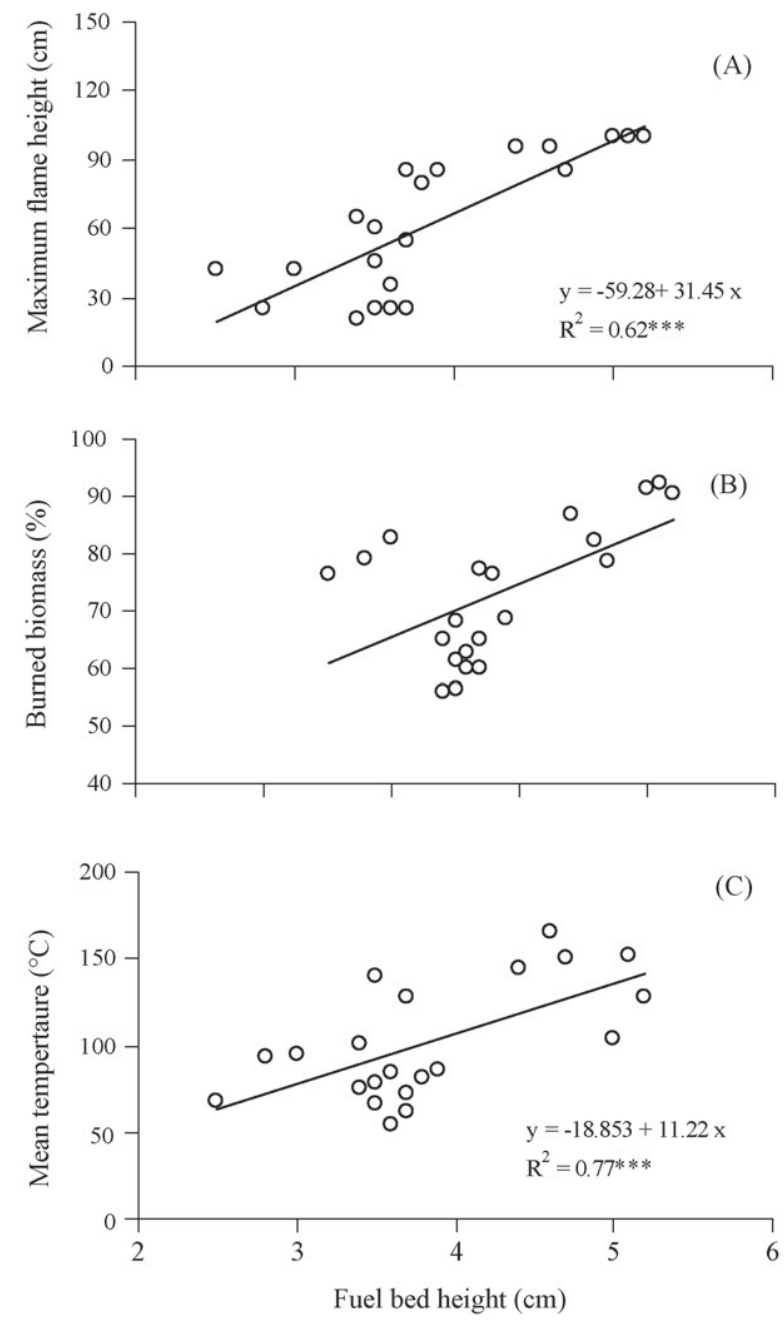

Fig. 3. Correlation between fuel bed height and maximum flame height (A), burned biomass (B) and mean temperature (C), obtained with burn table. Correlations with the rest of fire properties (combustion time and spread rate) were not significant in MRA and are not shown. Only data of fuels where fire was propagated are shown $(P$. pinaster, $P$. halepensis, $P$. pinaster $+P$. halepensis, $P$. pinaster $+P$. pinea $P$. pinaster $+C$ albidus, $P$. pinaster $+C$. ladanifer, $P$. pinaster $+C$. laurifolius $) . n=21$, since 3 fuel beds were studied for each fuel type.

Likewise, spread rate was significantly different according to the fuel bed composition (Kruskal-Wallis, $P<0.05$, Table 2). Fuel of $P$. pinaster, $P$. halepensis and $P$. pinaster $+P$. halepensis were consumed at a significantly higher mean rate in comparison to the other fuels (NSK, Table 2). In contrast, flame progressed slowly when leaf litter beds were formed by P. pinaster + Cistus sp. As for the other flammability properties, intermediate spread rates were obtained when $P$. pinaster was burned with needle litter of $P$. pinea. Only terpene content predicted spread rate variations (MRA, bed height: $P>0.05$, terpene content: $P<0.05$, Table 3). Because the highest and the lowest spread rates occurred for leaf litter with the highest and the lowest terpene concentrations respectively, these variables were negatively correlated (RA, $P<0.001$, Fig. 2C). Apart $\beta$-pinene and $\gamma$-muurolene, all terpenes ( $\alpha$-pinene, $\alpha$-humulene, $\beta$-caryophyllene, $\gamma$-cadinene, $\delta$-cadinene and caryophyllene oxide) were significantly correlated to spread rate (RA, $0.001<P<0.05$, Fig. 4C). The linear relationship was especially high for caryophyllene oxide $\left(R^{2}=0.83\right)$ and lower for cadinene $\left(R^{2}=0.51\right)$. Sesquiterpenes showed greater slopes than $\alpha$-pinene, demonstrating again that increases in sesquiterpene contents resulted in high increases in flammability. 
Monoterpenes and oxygenated sesquiterpenes

Sesquiterpenes
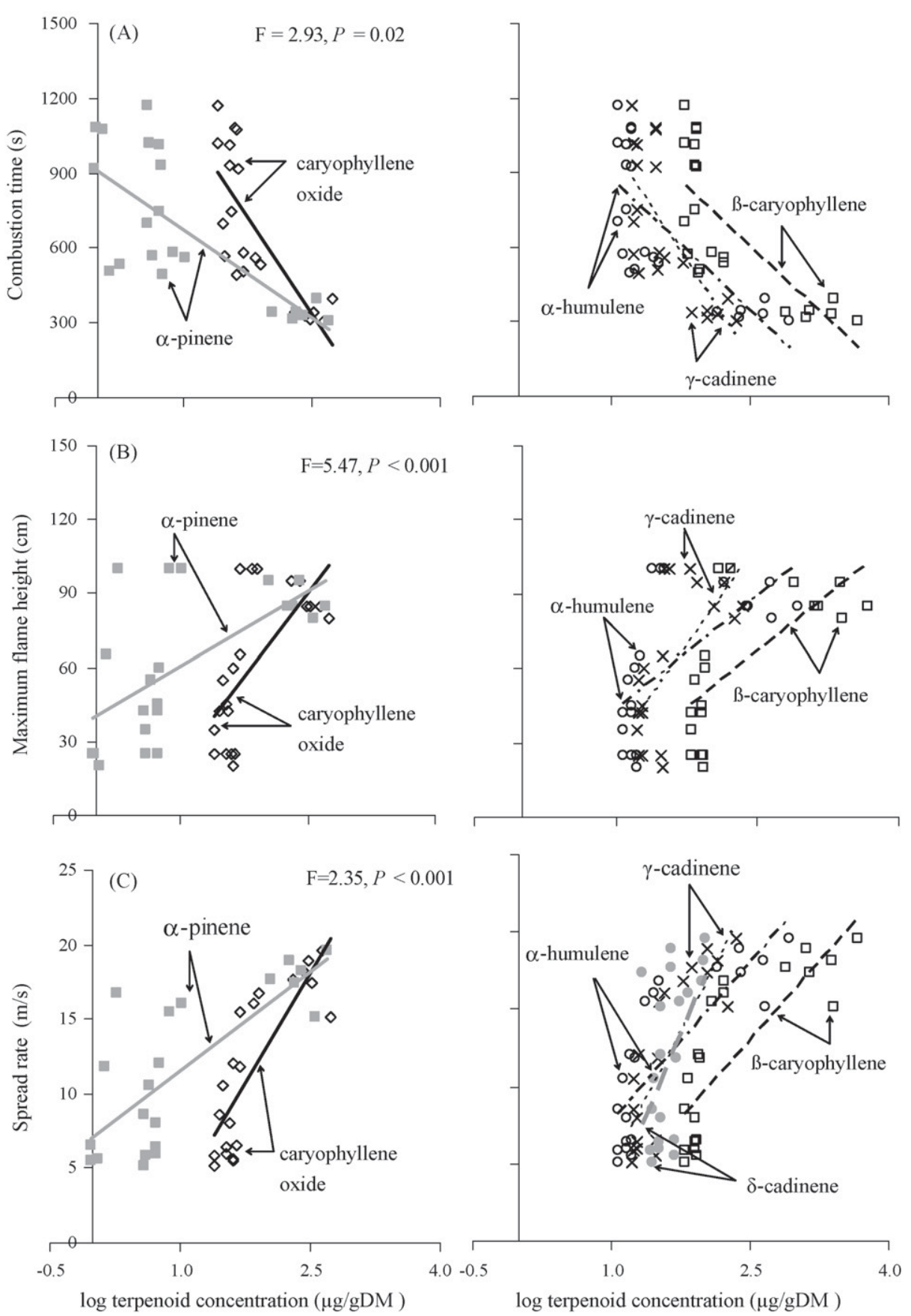

Fig. 4. Correlations between concentration (after log transformation) of single terpenes in leaf litter and combustion time (A), flame height (B), and spread rate (C) obtained with burn table. Correlations with the rest of fire properties (combustion time and spread rate) were not significant in MRA and are not shown. Only data of fuels where fire was propagated are shown (P. pinaster, P. halepensis, P. pinaster + P. halepensis, $P$. pinaster + P. pinea, P. pinaster + C. albidus, $P$. pinaster + C. ladanifer, $P$. pinaster + C. laurifolius) . $n=21$, since 3 fuel beds were studied for each fuel type. $n=19$ for $\alpha$-pinene, $n=17$ for $\beta$-pinene and $n=21$ for $\alpha$-humulene, $\beta$-caryophyllene, $\gamma$-cadinene, $\delta$-cadinene, and caryophyllene oxide. $N$ varies according to the compound, because some compounds were not present in some fuels (see Table 1 ).

Percentage of burned biomass was significantly higher during burns of $P$. pinaster and $P$. pinaster $+P$. halepensis, in comparison with $P$. pinaster $+C$. albidus and $P$. pinaster $+C$. laurifolius (NSK, Table 3). In contrast to the other variables describing fire behavior, the percentage of burned biomass could only be predicted by bed height instead of terpene content (MRA, bed height: $P<0.05$, terpene content: $P>0.05$, Table 3 ). Indeed, leaf litter of $P$. halepensis exhibited the higher terpene concentration but only showed an intermediate percentage of burned biomass. A significant linear relationship appeared between the percentage of burned biomass and bed height (RA, $P<0.01$, Fig. 3B).

Maximum and minimum temperatures did not significantly vary among the different types of leaf litter (Kruskal-Wallis, $P>0.05$, Table 2), whereas significant differences appeared for 
mean temperatures $(P<0.05)$. During burns of leaf litter of $P$. pinaster $+P$. halepensis and $P$. pinaster $+C$. ladanifer, the lowest and highest mean temperatures occurred, respectively (NSK, Table 2). Changes in mean temperature could be significantly estimated by bed height only (MRA, bed height: $P<0.05$, terpene content: $P>0.05$, Table 3 ). These variables were positively correlated (RA, $P<0.01$, Fig. 3C).

\subsection{Leaf litter flammability calculated through epiradiator tests and relationship with terpene content}

Ignition frequency was $100 \%$ for all leaf litter combinations; no significant differences in the ignition delay were observed between different leaf litters (one-way ANOVA, $P>0.05$, Fig. 5A). There was, however, a negative relationship between the ignition delay and leaf litter terpene content $\left(R^{2}=0.40, P<0.05\right.$, Fig. $\left.6 \mathrm{~A}\right)$, indicating that ignitability is favored by high terpene concentrations in leaf litter. With the exception of $\gamma$-muurolene and $\delta$-cadinene, concentration of selected terpenes ( $\alpha$-pinene, $\beta$-pinene, $\alpha$ humulene, $\beta$-caryophyllene, $\gamma$-cadinene and caryophyllene oxide) was also negatively correlated with the ignition delay $(0.0001<P<0.04)$, with the highest $R^{2}$ for $\alpha$-humulene $(0.76)$ and the lowest $R^{2}$ for $\beta$-caryophyllene (0.38) (Fig. 4A). No significant differences among their slopes were observed (ANCOVA, $P>0.05$, Fig. 7A), indicating that variations in flammability can be equally estimated from any of these compounds.

Flame residence time varied significantly among leaf litters (one-way ANOVA, $P<0.05$, Fig. 5B). For $C$. ladanifer and $C$. laurifolius, species with the lowest terpene content, a slower burning time (lower flame residence time) was observed in comparison with the three Pinus species and C. albidus, indicating a lower combustibility (Duncan test, Fig. 5B). For example, flame residence time for $P$. halepensis was $70 \%$ that of $C$. laurifolius. A significant negative linear relationship was thereby observed between the flame residence time and leaf litter terpene concentration $\left(R^{2}=0.40, P<0.05\right.$, Fig. $\left.6 \mathrm{~B}\right)$. This linear relationship was found as well for $\alpha$-pinene, $\alpha$-humulene, $\beta$-caryophyllene, $\gamma$ cadinene, $\delta$-cadinene and caryophyllene oxide, with no significant differences among their slopes (ANCOVA, $P>0.05$, Fig. 7B).

Flammability intensity (in terms of flame height, see Section 2), was significantly different between fuels (one-way ANOVA, $P<0.05$, Fig. 5C). Leaf litter with the highest terpene concentrations, i.e. $P$. halepensis, showed significantly higher flammability intensities than $P$. pinaster. When leaf litter of $P$. pinaster was burned together with that of $P$. halepensis, flammability intensity reached values as high as for $P$. pinaster alone. These three litter fuels presented significantly higher flammability intensities in comparison with any of the other fuels (Duncan test, Fig. 5C). Because these fuels also showed high terpene concentrations, a positive relationship between flammability intensity and total terpene content appeared (RA, $P<0.05$, Fig. 6C). Additionally, flame intensity could also be significantly estimated from concentration of $\alpha$-pinene, $\alpha$-humulene, $\beta$-caryophyllene, $\gamma$ cadinene and caryophyllene oxide (RA, $0.002<P<0.02$, Fig. 7C). The relationship was especially high for $\alpha$-pinene $\left(R^{2}=0.77\right)$ and lower for $\gamma$-cadinene $\left(R^{2}=0.47\right)$. There were, however, no significant differences between their slopes (ANCOVA, $P>0.05$, Fig. 7C).

Results of flammability obtained with both the epiradiator and burn table could be summarized as follows: (1) the top flammability leaf litters where those of $P$. halepensis, $P$. pinaster and $P$. pinaster $+P$. halepensis. Intermediate flammability was observed for $P$. pinea, $C$. albidus, $P$. pinaster $+C$. albidus and $P$. pinaster + P. pinea. $C$. ladanifer, $C$. laurifolius, while the combination of their litter with that of $P$. pinaster were the less flammable, (2)
Pinus sp. showed overall a higher flammability than Cistus sp. (3) under high terpene concentrations in dead leaves, combustion time (burn table tests), ignition delay, and flame residence time (epiradiator tests) diminish, whereas spread rates (burn table tests) and flame intensity (epiradiator tests) rise. The highest flame heights (burn tables) were related to both high terpene concentrations and bed heights, and the highest percentages of burned biomass were associated with the highest thickness of fuel beds.

\section{Discussion}

Leaf litter constitutes the most substantial component of total litter on forest floor (Proksch et al., 1982). The importance of this non-woody surface fuel in wildfires has been addressed in numerous studies in terms of the effects of its arrangement (Bradstock and Cohn, 2002) and morphology (Scarff and Westoby, 2006), but no study has attempted to evaluate the relationship between terpene content and a range of different metrics of flammability of leaf litter. Results available in the literature on this relationship regard green leaves, and are controversial. Owens et al. (1998), in concurrence with this study, showed that terpene concentration in green leaves has a positive effect on leaf flammability. However, these authors measured flammability as the percentage of burned biomass of Juniper ashei J. Buchholz. trees, whereas in the present study, this flammability parameter was correlated to bed thickness and not to terpene content. Alessio et al. (2008a), contrary to findings herein, showed no significant differences in flammability (time elapsed to reach flame) between $Q$. ilex and $P$. halepensis, despite the fact that the former is a nonstoring species while $P$. halepensis stores important concentrations of terpenes in its needles. Furthermore, Alessio et al. (2008b) showed no significant correlation between leaf terpene content and the ignition delay time for $P$. halepensis, Rosmarinus officinalis $\mathrm{L}$. and Pistacia lentiscus L., even if this correlation was significant for Globularia alypum.

In spite of little evidence of effects of plant terpene content on fire behavior, it is generally accepted that the presence of terpenes in plants highly increases the risk of wildfires (Nuñez-Regueira et al., 2005). This assumption is based on the evidence that highly flammable gases (volatile organic compounds) accumulate when a species rich in terpenes is submitted to thermal decomposition under conditions of low turbulence: the accumulation of these gases may produce flammable concentrations near leaves and may facilitate the propagation of wildfires (Greenberg et al., 2006).

Tests with burn tables revealed that fire was self-extinguished for pure fuels formed by leaf litter of $P$. pinea, $C$. albidus, $C$. ladanifer and $C$. laurifolius. Since these species showed lower terpene contents than $P$. pinaster and $P$. halepensis, for which fire was selfspread, this suggests that there might be a lower limit for litter terpene concentration, below which fire is not self-propagated. This hypothesis is based on the fact that any flammable compound or mixture has a minimum concentration (LFL) below which flame is not propagated (Affens and Carhart, 1966). Scarff and Westoby (2006) also showed that several Callistris conifer species did not self-sustain fire, even if it was also artificially assisted. Similarly, regarding the influence of litter, Bradstock and Cohn (2002) reported limited penetration of a wildfire into Callistris verrucosa stands. As both fuel structure and area-volume ratio are also involved in fire behavior (Fernandes and Rego, 1998; Bilandzija and Lindic, 1993), and beds of $P$. pinea, $C$. albidus, $C$. ladanifer and $C$. laurifolius also presented a higher thickness than $P$. pinaster and $P$. halepensis, we argue that bed thickness was also likely partially responsible for fire being self-extinguished. Therefore, terpene content could only partially explain why some species were not able to propagate fire. 

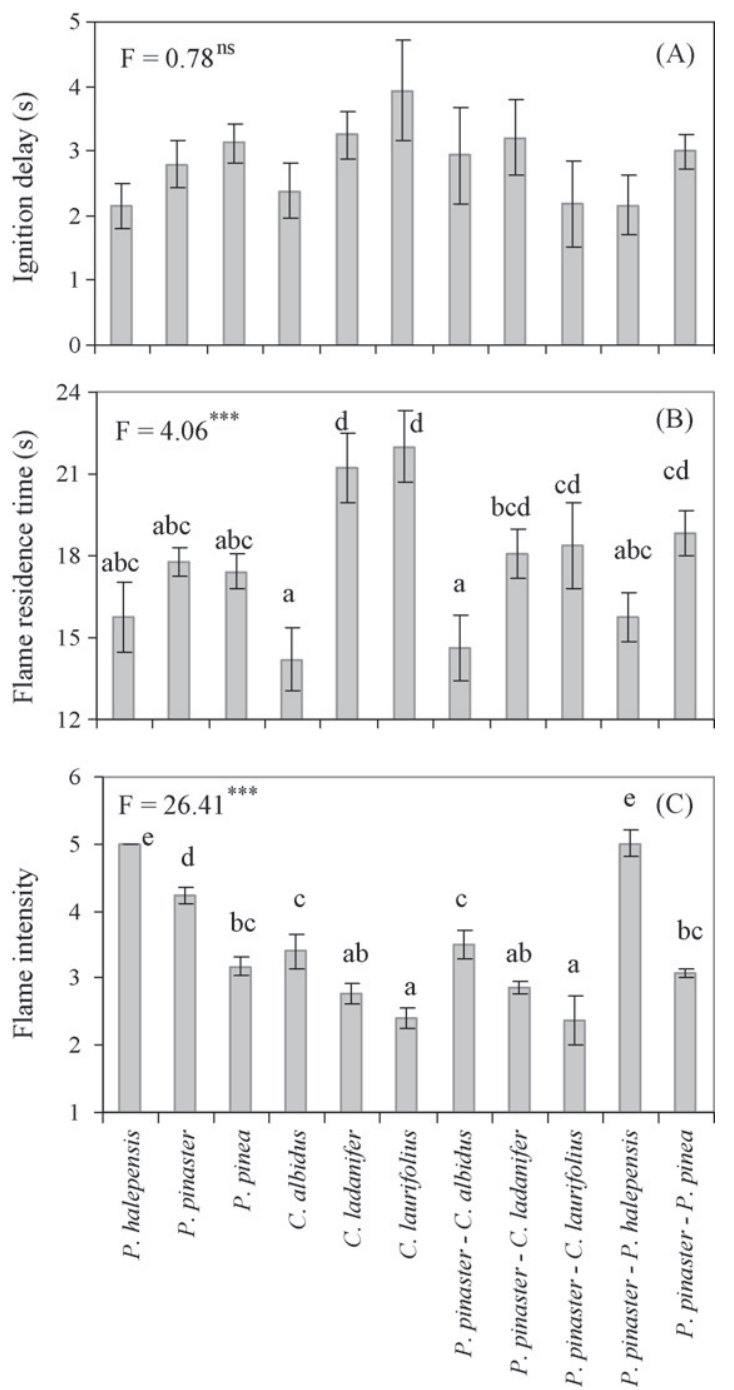

Fig. 5. Ignition delay (A), flame residence time (B) and flammability intensity (C) of eleven leaf litter fuels studied with the epiradiator. Flammability intensity is comprised between 1 and 5 when flame height during combustion was $<1 \mathrm{~cm}$, between 1 and $3 \mathrm{~cm}, 4$ and $7 \mathrm{~cm}, 8$ and $12 \mathrm{~cm}$ or $>12 \mathrm{~cm}$, respectively. Differences between fuels for A, B, C and D are tested through ANOVA followed by Duncan posthoc test. Different letters indicate significant differences $(a<b<c<d$, i.e. $a b=a$ and $\mathrm{ab}=\mathrm{b}), F$ : ANOVA value; ns: not significant $(P>0.05)$; ${ }^{* * *} P<0.001$. Bars represent mean \pm S.E. $(n=9)$.

Classification of natural fuels according to their expected flammability is an essential component of fuel hazard assessment (Dimitrakopoulos, 2001). In the present study, the highest flammability was assigned to leaf litter of $P$. halepensis, $P$. pinaster and $P$. pinaster $+P$. halepensis, and the lowest to that of $C$. laurifolius and $C$. ladanifer, which is of major importance in the Mediterranean area, where litter production of $P$. pinaster and $P$. halepensis is prevalent. For instance, mean litter production of these species in Spain has been reported to be $2400 \mathrm{~kg} \mathrm{ha}^{-1}$ year $^{-1}$ (Regina, 2001), 1728-3284 kg ha-1 year $^{-1}$ (Regina, 2001; Roig et al., 2005), respectively. We suggest therefore, that the management of dead fuel be given priority in mixed or monospecific dense forests of these Pinus sp.

$P$. pinaster and $P$. halepensis have already been reported to be highly flammable; $P$. pinaster is generally known to be highly flammable due to the quality, quantity and structural arrangement of its fuels (Fernandes and Rigolot, 2007). Nimour Nour (1997) noted that total carbohydrate content of $P$. halepensis was directly
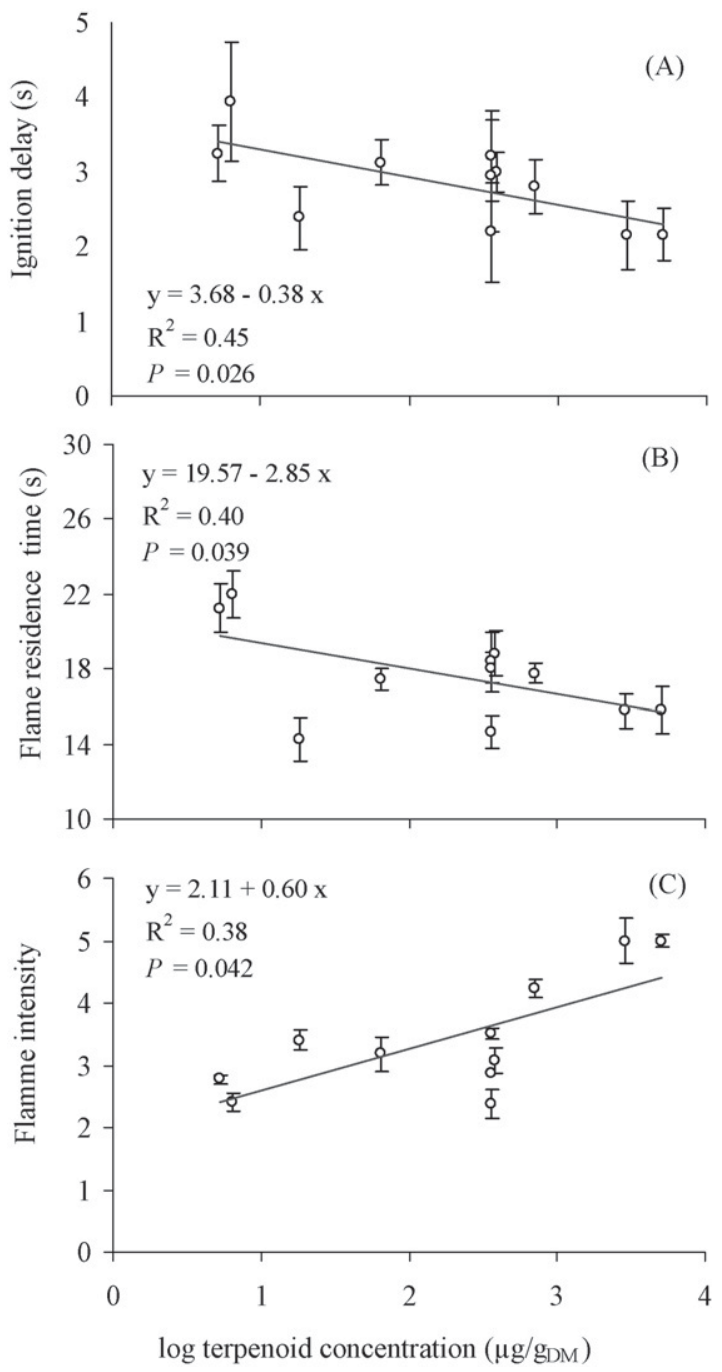

Fig. 6. Correlation between total terpene concentration (after log transformation) and flammability in terms of ignition delay (A), flame residence time (B) and flame intensity $(C)$ obtained with the epiradiator. Flammability intensity is comprised between 1 and 5 when flame height was $<1 \mathrm{~cm}$, between 1 and $3 \mathrm{~cm}, 4$ and $7 \mathrm{~cm}, 8$ and $12 \mathrm{~cm}$ or $>12 \mathrm{~cm}$, respectively. Each point represents mean $\pm S$.E. for each fuel. The mean for terpene content and flammability was calculated as the average of 9 and 30 samples, respectively.

correlated with fire frequency and burned areas during summer. Accordingly to this work, Petriccione et al. (2006), without attempting to associate litter flammability to any litter chemical property, showed a low or null flammability for Cistus sp. ( $C$. salvifolius, $C$. lentiscus and $C$. incanus) in comparison with $P$. halepensis and P. pinaster. Additionally, Martin and Juhren (1954) suggested that plantations of Cistus sp. could be a useful tool in brush-fire control by improving the effectiveness of fire breaks, based on the observation that several members of the Genus Cistus burned less readily than chaparral species.

Mutch (1970) formulated the hypothesis that natural selection would favor the development of highly flammable species that perpetuate a given fire environment. The question arises as to whether highly flammable species, such as $P$. pinaster and $P$. halepensis, which have evolved adaptations for surviving against fire, may later benefit from it. For instance, these conifer species mainly produce serotinous cones that represent a fire-survival strategy since they need high temperatures in order to open 
Monoterpenes and oxygenated sesquiterpenes Sesquiterpenes
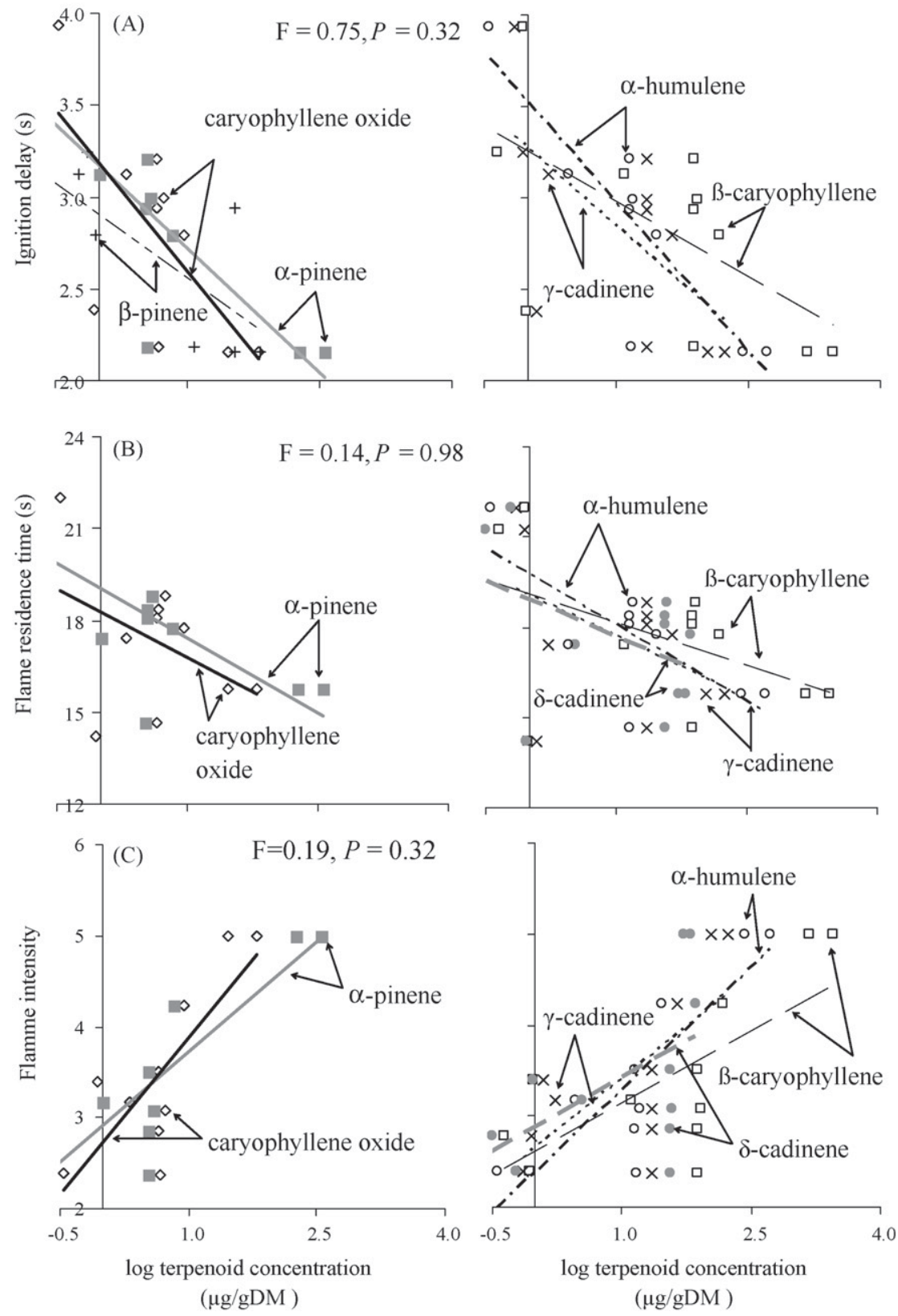

Fig. 7. Correlation between concentration (after log transformation) of single terpenes and ignition delay (A), flame residence time (B) and flame intensity (C), obtained with the epiradiator. Slope differences are tested with ANCOVA test. Flammability intensity is comprised between 1 and 5 when flame height was $<1 \mathrm{~cm}$, between 1 and $3 \mathrm{~cm}, 4$ and $7 \mathrm{~cm}, 8$ and $12 \mathrm{~cm}$ or $>12 \mathrm{~cm}$, respectively. Each point represents mean of a fuel type. S.E. are not shown to increase graph visibility. The total number of points (i.e. of fuels) ranges between 9 and 11 according to the compound, since some compounds were not present in some fuels (Table 1). F: ANCOVA value.

(Tapias et al., 2000). Nonetheless, these species regenerate profusely after fire, since they reproduce exclusively from seeds (i.e. they do not sprout) and their dispersion hence partially depends on the openness of these cones (Tapias et al., 2000; Ne'eman et al., 2004). A greater accumulation of terpenes in their green leaves, and the subsequent accumulation of these compounds in their needle litter, would hence allow them to increase fire risk, which in turn would partially increase their odds of dispersal in their environment, subsequent to fire. Plants might thus indirectly influence fire intensity that they and their offspring experience, rather than simply developing traits to survive fire.

Because Pinus sp. were overall more flammable than Cistus sp., these results confirm that narrow needle-like leaves have a higher flammability (Tartaglini et al. 1992, in, Alessio et al., 2008b). However, since species showing similar leaf morphologies but different terpene concentrations had differences in flammability (e.g. P. pinaster versus $P$. pinea, or $C$. albidus versus $C$. ladanifer), it is suggested that when leaf litter exhibit similar morphologies, terpene concentration might be used as a criterion to estimate their flammability, and therefore their impact on fire in natural ecosystems.

Can we identify compounds accounting for flammability differences between fuels? Results from table burns revealed that flammability is more sensitive to changes in sesquiterpenoid than monoterpenoid concentrations. Particularly, combustion time, flame height and spread rate were more responsive to changes 
in $\alpha$-humulene, $\beta$-caryophyllene, and caryophyllene oxide concentration than changes in $\alpha$-pinene and $\beta$-pinene. Additionally, these results imply that fuels that diverge principally in their monoterpenoid content are likely to show slight differences in flammability. It is important to note that this assumption would uniquely be applicable if temperatures reached were similar to those recorded in this study. Indeed, under lower temperatures, monoterpenes would volatilize rather sesquiterpenes since they need lower temperatures than sesquiterpenes to volatilize and form an ignitable mixture owing to their lower flash point (e.g. $\beta$ pinene: $47^{\circ} \mathrm{C}, \beta$-caryophyllene: $100{ }^{\circ} \mathrm{C}$, caryophyllene oxide: $110^{\circ} \mathrm{C}$, Sigma-Aldrich data).

A different temperature protocol could therefore result in a different flammability ranking. For instance, Petriccione et al. (2006), using an epiradiator set at $250^{\circ} \mathrm{C}$, reported a higher flammability for $P$. pinaster needle litter than for $P$. halepensis, while the opposite trend was found in this study with the epiradiator set at $420^{\circ} \mathrm{C}$. Likewise, fuel flammability may vary according to the technique employed. Flame height was higher for $P$. pinaster than for $P$. halepensis during table burns, whereas inversely, $P$. halepensis showed longer flames than $P$. pinaster with the epiradiator. Our study reveals that flame height is also clearly sensitive to fuel loads and their arrangement, explaining differences observed between techniques.

\section{Conclusions}

This work demonstrates that terpene concentration increases most flammability components of leaf litter (sustainability, ignitability and combustibility) with Pinus sp. containing simultaneously a higher terpene concentration and flammability than Cistus sp. Thereby, in addition to the physical factors of each fuel, terpene accumulation in leaf litter could be considered as a natural chemical factor having an impact in fire risk.

Since needle litter of $P$. halepensis and $P$. pinaster were the most flammable, forest ecosystems in which these are the predominant species are anticipated to show a high risk of flammability during summer drought periods, when environmental temperatures and atmospheric stability (absence of turbulences) allow the creation of a highly flammable atmosphere. Although numerous Mediterranean species are prone to fire, owing to their intrinsic morphological and physiological characteristics, the need to find which species are less flammable becomes therefore crucial to minimize fire consequences in the Mediterranean area.

\section{Acknowledgements}

We are grateful to Colonel Claude PICARD director of the CEREN (Centre d'Essais et de Recherche de l'Entente Interdépartementale en vue de la Protection de la Forêt et de l'Environnement contre l'incendie) and his assistant Frédérique GIROUD for the technical support for flammability tests.

\section{References}

Adams, R.P., 2007. Gas chromatograph/mass spectrometry. In: Identification of Essential Oil Components by Gas Chromatography/Mass Spectrometry, Allured Publishing Corporation, Carol Stream, IL.

Affens W.A., Carhart, H.W., 1966. The effect of ullage on the flash point and lower flammability limit temperatures of jp-5 jet fuels. Memorandum report $10 \mathrm{pp}$. Naval Research Laboratory.

Alessio, G., Peñuelas, J., De Lillis, M., Llusia, J., 2008a. Implications of foliar terpene content and hydration on leaf flammability of Quercus ilex and Pinus halepensis plant. Ecology 10, 123-128.

Alessio, G., Peñuelas, J., Lusia, J., Ogaya, R., Estiarte, M., De Lillis, M., 2008b. Influence of water and terpenes on flammability in some dominant Mediterranean species. Int. J. Wildland Fire 17, 274-286.
Alía, R., Martín, S., De Miguel, J., Galera, R., Agúndez, D., Gordo, J., Salvador, L., Catalán, G., Gil, L., 1996. Las regiones de procedencia de Pinus pinaster Aiton. In: Ministerio de Medio Ambiente. Organismo Autónomo Parques Nacionales, Madrid.

Behm, A.L., Duryea, M.L., Long, A.J., Zipperer, W.C., 2004. Flammability of native understory species in pine flatwood and hardwood hammock ecosystems and implications for the wildland-urban interface. Int. J. Wildland Fire 13, 355-365.

Bilandzija, J., Lindic, V., 1993. Influence of forest fuel structure on fire behaviour in aleppo pine stands. Radovi - Sumarski Institut Jastrebarsko 28, 215-224.

Bradstock, R.A., Cohn, J.S., 2002. Fire regimes and biodiversity in semi-arid mallee ecosystems. In: Bradstock, R.A., Williams, J.E., Gill, A.M. (Eds.), Flammable Australia: The Fire Regimes and Biodiversity of a Continent. Cambridge University Press, Cambridge, UK, pp. 238-258.

Brooks, M.L., D’Antonio, C.M., Richardson, D.M., 2004. Effects of invasive alien plants on fire regimes. Bioscience 54, 677-688.

CEREN, 2006. Emission de composés organiques volatils au sein des formations végétales méditerranéennes et relation avec les potentialités d'inflammation. In: Ministère de l'Agriculture GIS incendies report, pp. 122-170.

Derory, J., Mariette, S., Gonzalez-Martinez, S., Chagne, D., Madur, D., Gerber, S., Brach, J., Persyn, F., Ribeiro, M., Plomion, C., 2002. What can nuclear microsatellites tell us about maritime pine genetic resources conservation and provenance certification strategies? Ann. Forest. Sci. 59, 699-708.

Dimitrakopoulos, A.P., 2001. A statistical classification of Mediterranean species based on their flammability components. Int. J. Wildland Fire 10, 113-118.

European Commission, 2006. Forest fires in Europe. In: JRC-IES/Land Management \& 534 Natural Hazards Unit, Luxemburg, Italy, p. 535

Farhat, G.N., Affara, N.I., Gali-Muhtasib, H.U., 2001. Seasonal changes in the composition of the essential oil extract of East Mediterranean sage (Salvia libanotica) and its toxicity in mice. Toxicon 39, 1601-1605.

Fernandes, P.M., Rego, F., 1998. A new method to estimate fuel surface area-tovolume ratio using water immersion. Int. J. Wildland Fire 8, 121-128.

Fernandes, P.M., Rigolot, E., 2007. The fire ecology and management of maritime pine (Pinus pinaster Ait.). Forest. Ecol. Manage. 241, 1-13.

Greenberg, J.P., Friedli, H., Guenther, A.B., Hanson, D., Harley, P., Karl, T., 2006. Volatile organic emissions from the distillation and pyrolysis of vegetation. J. Geophys. Res, Atmos. 6, 81-91.

Hernando-Lara, C., 2000. Combustibles forestales: inflamabilidad. In: Vélez Muñoz, R. (Ed.), La defensa contra incendios forestales, fundamentos y experiencias, vol. 6McGraw-Hill, pp. 15, pp. 3-6.

Hogkinson, K.C., 2002. Acacia wooded landscapes: effects on functional processes and biological diversity. In: Bradstock, R.A.,Williams, J.E.,Gill, A.M. (Eds.), Flammable Australia: The Fire Regimes and Biodiversity of a Continent. Cambridge University Press, Cambridge, UK, pp. 259-277.

Isidorov, V.A., Vinogorova, V.T., Rafalowski, K., 2003. HS-SPME analysis of volatile organic compounds of coniferous needle litter. Atmos. Environ. 37, 4645-4650.

Llusià, J., Peñuelas, J., 2000. Seasonal patterns of terpene content and emission from seven Mediterranean woody species in field conditions. Am. J. Bot. 87, 133-140.

Mackinnon, A.J., 1987. The Effect of the Composition of Wood on its Thermal Degradation. Strathclyde University, Glasgow (United Kingdom).

Martin, L., Juhren, M., 1954. Cistus and its response to fire. Lasca Leaves 4, 65-67.

Mitchell, D., Coley, P., Webb, S., Allsopp, N., 1986. Litterfall and decomposition processes in the coastal Fynbos vegetation, Southwestern Cape South-Africa. J. Ecol. 74, 977-993.

Montgomery, K.R., Cheo, P.C., 1971. Effect of leaf thickness on ignitibility. Forest Sci. $17,475-478$.

Morandini, F., Santoni, P.A., Balbi, J.H., 2001. The contribution of radiant heat transfer to laboratory-scale fire spread under the influences of wind and slope. Fire Safety J. 36, 519-543.

Mutch, R.W., 1970. Wildland fires and ecosystems-a hypothesis. Ecology 51, 10461051.

Mutch, R.W., Philpot, C.W., 1970. Relation of silica content to flammability in grasses. Forest Sci. 16, 64-65 (62).

Ne'eman, G., Goubitz, S., Nathan, R., 2004. Reproductive traits of Pinus halepensis in the light of fire-a critical review. Plant Ecol. 171, 69-79.

Nimour Nour, E., 1997. Inflammabilité de la végétation méditerranéenne. Thesis report. Aix-Marseille University, Marseille, France.

Nuñez-Regueira, L., Rodriguez-Anon, J.A., Proupin, J., Mourino, B., Artiaga-Diaz, R., 2005. Energetic study of residual forest biomass using calorimetry and thermal analysis. J. Therm. Anal. Calorim. 80, 457-464.

Ormeño, E., Fernandez, C., Mévy, J.P., 2007. Plant coexistence alters terpene emission and content of Mediterranean species. Phytochemistry 68, 840852 .

Owens, M.K., Lin, C.D., Taylor, C.A., Whisenant, S.G., 1998. Seasonal patterns of plant flammability and monoterpenoid content in Juniperus ashei. J. Chem. Ecol. 24, 2115-2129.

Pausas, J.G., Vallejo, V.R., 1999. The role of fire in European Mediterranean ecosystems. In: Chuvieco, E. (Ed.), Remote Sensing of Large Wildfires in the European Mediterranean Basis. Springer-Verlag, Berlin, pp. 3-16.

Pellizzaro, G., Duce, P., Ventura, A., Zara, P., 2007. Seasonal variations of live moisture content and ignitability in shrubs of the Mediterranean Basin. Int. J. Wildland Fire 16, 633-641.

Pereira, J.M.C., Santos, M.T., 2003. Areas Queimadas e Risco de Incêndio em Portugal. DGF, MADRP, Lisboa.

Petriccione, M., Moro, C., Rutigliano, F.A., 2006. Preliminary studies on litter flammability in Mediterranean region. Forest. Ecol. Manage. 234S. 
Proksch, P., Proksch, M., Rundel, P.W., Rodriguez, E., 1982. Ecological significance of the chemistry of the leaf resin of Elytropappus rhinocerotis. Biochem. Syst. Ecol. $10,49-53$.

Regina, I.S., 2001. Litter fall, decomposition and nutrient release in three semi-arid forests of the Duero basin. Spain. Forest. 74, 347-358.

Roig, S., del Rio, M., Canellas, I., Montero, G., 2005. Litter fall in Mediterranean Pinus pinaster Ait. stands under different thinning regimes. Forest. Ecol. Manage. 206, 179-190.

Scarff, F.R., Westoby, M., 2006. Leaf litter flammability in some semi-arid Australian woodlands. Funct. Ecol. 20, 745-752.

Schwilk, D.W., 2003. Flammability is a niche construction trait: canopy architecture affects fire intensity. Am. Nat. 162, 725-733.
Tapias, L.G., Fuentes-Utrilla, P., Pardos, J.A., 2000. Canopy seed banks in Mediterranean pines of south-eastern Spain: a comparison between Pinus halepensis Mill., P. pinaster Ait., P. nigra Arn. and P. pinea L. J. Ecol. 89, 629.

Trabaud, L., 1976. Inflammabilité et combustibilité des principales espèces des garrigues de la région méditerranéenne. Oecolog. Plantar 11, 117-136.

Walter, J., Charon, J., Marpeau, A., Launay, J., 1989. Effects of wounding on the terpene content of twigs of maritime pine (Pinus pinaster Ait). I. Changes in the concentration of diterpene resin acids and ultrastructural modifications of the resin duct epithelial cells following injury. Trees 3, 210-219.

White, C., 1994. Monoterpenes: their effects on ecosystem nutrient cycling. J. Chem. Ecol. 20, 1381-1406. 